Boise State University

ScholarWorks

8-1-2012

\title{
Negotiating Conflicting Rhetorics: Rancheras and Documentary in the Classroom
}

Dora Ramirez-Dhoore

Boise State University 


\section{Negotiating Conflicting Rhetorics: Rancheras and Documentary in the Classroom}

\section{Dora Ramirez-Doore \\ Boise State University}

As a young teenager, I remember sitting in the back seat of my parent's car, rolling my eyes at the noise coming from the radio speakers. On the airwaves being sent directly from Texas and Florida and behind the overbearing static sound, I could make out the TAN, TAN of the ending of the ranchera ${ }^{1}$ song my father was singing and enjoying. My mother would be next to him singing and whistling along, ignoring the static sound that was louder than the music and that would invariably give my teenage self a headache. ${ }^{2}$ My sister and I, two teenagers growing up in a small town in Eastern Oregon and adoring European bands like Duran Duran, Depeche Mode, and The Cure would complain, or should I say whine about the "music" our parents were so willing to hold on to even through the static.

Ironically, even after all my attempts to get my parents to change the station from their static rancheras to 92 KISS FM, today I find myself nostalgically searching the radio channels for Mexican music or Spanish-speaking stations. Fortunately, I don't have to search that long, as Latino music is now on the FM and digital airwaves in the most rural parts of the United States, making it accessible to Latino/a populations in the smallest of towns. My experiences have made me realize that this music is a text that is connected to individuals on many levels, superceding that of just plain nostalgia. The fact is that today, after many years of making it through new musical genres and trends, rancheras are not only about the appreciation of music, but about the socio-cultural issues that are present within the individual listening to this music. Whether it be the person whose driving down the street with the radio blaring and the car thumpin,' the father who sits in his home with headphones on so as not to disturb his teenage daughters' assimilation tendencies, or the college professor who theorizes about the social and political significance of this music, these listeners are ascribing cultural and gendered meaning to this music. My resistance to ranchera music as a teenager growing up in a northern state was more than adolescent rebellion to my parent's music, making this cultural crux an important site of reflection for educators. My resistance involved not wanting to be seen as that kind of Mexican, which in my mind at 
the time was of the migrant working, labor class of which I was a member. Although the statement often angered me, I naively believed in that harmful phrase that deems one more important than their community which stated "Oh, (enter first name), you're different than them." I now focus on the word difference as that which causes so much frustration for many of the students that come into my classroom on a daily basis. My resistance to rancheras involved a great misunderstanding of my own culture, and most unfortunately, it involved giving into the structure of dominance the "American" culture has acquired, thus it also involved a great (mis)understanding of United States culture.

My own narrative made me realize that individual experience with music is not separate from our classrooms. In fact, music is the everyday, thus giving educators access to a site where critical thinking about our social atmosphere is set to happen through writing, reading, and listening. This essay offers an alternative literacy to both the students and educators unfamiliar with this patriarchal and cultural music and those who are immersed in it and who constantly negotiate conflicting cultural narratives. By analyzing ranchera music through a feminist lens and by incorporating the aural, visual, and written rhetoric that it encompasses, this essay offers alternative ways of engaging texts that work through colonialism and the rhetorical map that travels South-North. This analysis also offers those who live north of "up north" a way to theorize about the homeland and the borderlands that exist, and that due to antiMexican legislation are becoming more delineated daily.

Through music we can see that song, story, and social myths are intertwined. The patriarchal, nationalistic, and gendered myths are imbedded in the music that many students listen to, thus it should be listened to critically. In the introduction to Attending the Margins, Michelle Hall Kells and Valerie Balester question "if our metaphors have become our myths, our disabling fictions. Has our notion of la frontera as border inadvertently advanced the construction and perpetuation of a host of disabling fictions?" (xix) As Kells and Balester attempt to build new "enabling fictions," I join them by focusing on the music that overtly and covertly relies on these myths to define a specifically Mexicano border identity. This identity is at times essentialist and at other times, it pushes the borders of identity, falling 
under what Juan C. Guerra terms, "transcultural repositioning," which defined is a rhetorical skill "that members of our community must self-consciously regulate and not simply enact intuitively, if they wish to move back and forth with ease and comfort between and among different languages and dialects, different social classes, different cultural and artistic forms" (8). Guerra goes on to explain; "if enacted critically, transcultural repositioning can open the door to different ways of seeing and thinking about the increasingly fluid and hybridized world that is emerging around us[....]we may yet chart our own destiny and ensure that everyone among us is granted the right to personal agency and self-determination" (8). Most interesting about Guerra's words is the way they tie into what Ranchera music has thrived to achieve for almost a century. Self-determination and agency are two words which have provoked a multitude of songs to come out of the border regions of this country. Thus, Kells and Balester's myth of la frontera and Guerra's transcultural repositioning both tie into the way individuals perceive the dominant society — how they perceive language and music — how they perceive education — how they perceive success.

In discussing the work of teachers who understand the need of personalizing the historical, Kells and Balester explain, "they state or imply that students need to retain their sense of self, origin, identity as they venture into new discursive territory" (xviii). As I read this work and write about it here, I look back to the times I have wanted to listen to ranchera music as protest in my car in the Northwest, in a Mexican restaurant in the Midwest, or just to listen to it when I'm in the Rio Grande Valley of Texas. Am I essentializing this music to mean mexicano, when the academy has created and taught me a new discursive language in which I am to speak, write and publish? If this music is a fall back to homelandto language - to a comfortable place that is not destroyed by an academic language, then this could be construed as a romantic notion or nostalgia. I don't entirely agree, as this music, even though it is problematic in many ways, is the only understandable voice for some students, thus making the romantic notion or nostalgia sublime and necessary. It becomes a starting point for critical subjectivity.

Then, as a professor of Ethnic Literature in a predominately white institution, I can negotiate the difficult job of reaching certain students that resist discourses that remove them from the safety of their 
“comfort discourse." Students could then think about the reasons they listen to their favorite style of music and why they do not "like" other types of music (with ranchera music, I also incorporate the idea of international music that is unfamiliar to most students.) This is a symptom of what Donna Dunbar-Odom describes in, "Speaking Back with Authority" as "resistance." She sees this resistance as a "complex process" in which "many factors contribute to students seating themselves as far away from the teacher as possible" (8). This is a call for historicizing the personal and making the classroom a site for all discourses to be heard, spoken, and listened to as complete utterances and most importantly, not reinterpreted by a privileged discourse. This essay works toward redefining "American" culture through a feminist and a South-North paradigm - those concepts that begin in the borderlands, rather than the center. This is why a student's resistance or acceptance of any kind of music (and/or literature) can lead to a deeper critical understanding of the self in a complex world, thus leading to critical subjectivity and the negotiation of conflicting cultural rhetorics.

\section{The Texts in the Classroom}

Ranchera music specifically is bound by shifting cultural meanings that are produced by an individual or community. Individuals read and reformulate their interpretations of texts according to the stories or cultural myths that surround them. Thus, because canciones rancheras fit within a rhetorical history, this music should be taught rhetorically within a historical framework. To do this, I focus on Costa Rican filmmaker, Valeria Sarmiento's, Un Hombre, Cuando es Hombre (A Man, When He is a Man) who writes and reformulates the historically patriarchal and nationalistic nature of ranchera music through a feminist visual text. Within this documentary, Sarmiento uses footage from one of the most well known charros in Latin American cinema and music - actor and songwriter Jorge Negrete (height of career-1930-1950s) whose song "Mexico Lindo y Querido" describes the nationalistic sentiments imbedded in ranchera music.

Through the postcolonial idea of nationalistic memory, I help students focus on the economic systems, gendered systems, and the history at play in this music, thus moving "Mexican music" to a more 
transnational positioning. For instance, Jorge Negrete sings, "Voz de la guitarra mía,/Al despertar la mañana,/quiero cantar la alegría /De mi tierra mexicana." In translating this, he states, "Voice of my guitar/when I wake in the morning/I want to sing the joy/of my Mexican land." For Negrete, the individual, the land and the country are all part of the songs he sings — they are a part of his being —of his nationality. Song is memory for many of these artists and their listeners, and memory is history. But within this memory there is a male-centered rhetoric that incorporates the frustrations of a population that is oftentimes oppressed by the systems that surround them, whether politically, socially, economically, or sexually. These ideas work together as an ideology that furthers a male-centered rhetoric. This documentary is filled with images of these musicians dressed in traditional charro suits, looking quite debonair, while surrounded by gorgeous women, alcohol, or both—but always maintaining an image of manhood and resilience against oppression from anyone or any system. This unwarranted belief of manhood has become a sign of Mexican nationalism. This is then tied into patriarchy in order to create an image of nationalistic strength. This strength would then be carried into the idea of fighting class oppression for those immigrants working through difficult times in the United States. It is these nationalistic attitudes that then feed into ideologies (mine, the students, and what is expressed in the music), which I want students to analyze.

In addition to these attitudes, students also begin to understand the historical relationship they have to the socio-economic issues that surround the production of this music, thus it is productive to look at both the songs in the documentary and the documentary itself as texts. In "From Ranchero to Jaitón: Ethnicity and Class in Texas Mexican Music" Manuel Peña explains, "in 1946 at least three fourths of the Mexicans in Texas were working-class people who subscribed overwhelmingly to the ranchera music that conjuntos and the Mexican mariachi had so thoroughly popularized" (44). The dynamics of the listeners of this music has not changed much since 1946. According to Roland Soong in "Regional Music of Mexico," (2001) his compiled statistics of surveys of radio listeners in Latin America conducted by the TGI Mexico study, list thirty-one percent of the listeners of ranchera music in the lowest economic level, with only nine percent listening from the upper economic bracket. In addition to this, thirty percent had 
no comprehension of spoken English and fifty percent of the listeners of this music did not attend school.

Thus, rancheras, what became known as musica de la gente (music of the people), was aimed at the lower socio-economic classes of listeners in the United States.

This knowledge can be used in the classroom as one way to develop what Paulo Freire terms, critical subjectivity. Taking Ira Shor's advice in “Freire’s Critical Subjectivity: Questioning Self in Society," this project lends itself to Freire's idea of "historicizing the personal and personalizing the historical," and Shor's notion of "existentializing philosophy and philosophizing experience" (viii). From this, educators can focus on using music and the documentary, performed and created by Latina/os, as social tools in the classroom, where students can begin to take responsibility for reading and writing their world, because as Gloria Anzaldúa writes in the foundational text Borderlands/La Frontera, "there are more subtle ways that we internalize identification, especially in the forms of images and words" (83). In fact, because music is one of the most successful "cross-over" texts globally, educators can easily fit this into their pedagogical maps.

\section{Negotiating Conflicting Cultural and Gendered Rhetorics}

Heeding the personal and historical with images and words found in the music familiar to many Latina/o students illustrates how this music resides in the borderlands (Anzaldúa) and the multiple and dual identities students enter the classroom negotiating--me on the inside and student on the outside.

There is an understanding that this negotiation silences one rhetoric, usually that of the subaltern culture. ${ }^{3}$ José Angel Gutiérrez illustrates this negotiation (or lack of) when he explains the absence of research and knowledge he has met in his study of Mexican music. In "Chicano Music: Evolution and Politics to 1950," he begins to trace Mexican musicology through the Olmecs, Mayans, the Caribbean, the Moors, through Spanish colonization, and into contemporary historical influences. In his attempt at tracing this historical framework, he understands that a "problem associated with researching the origins of Chicano music is the lack of scholarship on its evolution. Historians have focused primarily on European music's influence on the indigenous, not the other way around" (171). This same attitude is prevalent in courses 
that I teach, where students have not been introduced to literature outside of the canon and do not see its importance on their critical subjectivity—-seeing it as marginal. This becomes one of the margins that as a faculty of color, I must negotiate in the classroom. It is history that often breaks these borders for students, by connecting the history of "American" music to that of Latin America (Shakira and Enrique Iglesias help in making this connection).

The colonial influence of an East/West concept is brought to the surface once again in discussing Mexican music historicity. Folklorist, Cándida F. Jáquez, writes of the "postrevolutionary period of the 1920s" when Mexican music was popularized as an act of resistance, a sentiment that continues to this day in reference to canciones rancheras, and especially corridos:

In the wake of Mexico's emergent nationalistic agenda, governmental policies evinced rapid, wide-scale reform for a country recovering from over a decade of instability. As part of this agenda, many writers and prominent thinkers argued for the ideological rejection of European forms as cultural models, of which the fine arts played a substantial role. It was a bold rejection of earlier attitudes that had valorized European culture as the scale against which cultural value and progress had been measured....This turn inward was marked by a primitivist aesthetic oriented toward discovering the true roots of mexicano culture. (168) Within this reform movement, there is an either/or mentality, which also continues for many individuals today. Thus, negotiations continue on a more personal level for many of the inheritors of the East/Westinfluenced history, especially for those individuals who may be second, third, fourth, or even fifth generation removed from Mexico, Central, or South America. For instance, when I listen to ranchera music I negotiate this dichotomy and I map this out for students when we discuss ranchera music in the documentary. I ask whether I listen to this music because of my connection to my cultural roots, or is it to reminisce about my adolescence. Or do I listen because when living in the Northern states I always wish I could see more Mexicanos, Chicanos and Indigenous peoples around me? Or is it simply my own guilt over my assimilation into mainstream culture? Regardless of the meaning I assign to this text, I point the students to the sense of ambiguity I feel when I purchase/listen to this music because of the ideology that 
has been attached to this style of music by friends, various academic scholars, popular culture critics, and feminists. The somewhat negative attitude toward "Mexican music" is not difficult to unearth in class discussion using concept maps on the board, thus what is important to unpack is the cultural ambiguity and attitudes that surround this music. Concept maps are useful in that they "help visual learners get their minds around abstract relationships" (Nilson 194), such as music, and it allows multiple perspectives to enter the dialogue without a full commitment to the ideas.

\section{Music as a Historical Text - Historicizing Rancheras}

Using Anzaldúa's theories, students begin to focus on the concept of history through autohistoria, which "deals with who tells the stories and what stories and histories are told" (113). If the student and educator allow music to tell a story and history, autohistoria has a forum in which to draw on the connections between the self and the student's culture - a connection Shor and Freire also make in their work to connect the personal and historical. This relationship gives attention to the class distinctions often made in and through music, including the dichotomy between low (often pop and popular) and high art, although the highly stereotyped genre of classical music should also be viewed through a socio-economic lens. The following concept map (see figure 1) broadly defines a way for students to begin placing themselves within the music they listen to or the one chosen by the instructor.

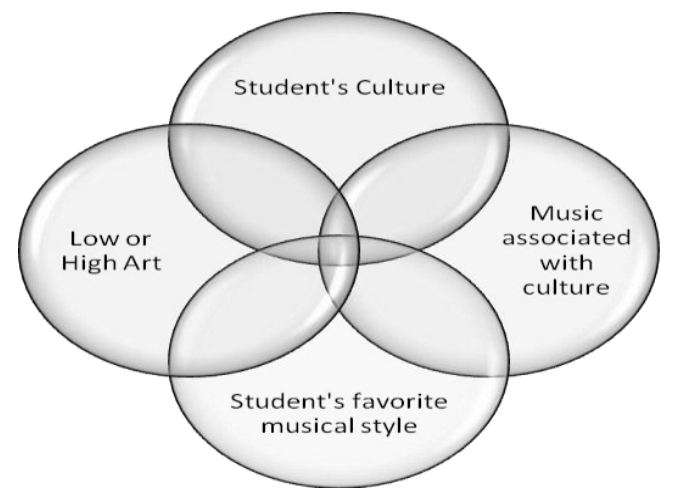

\section{Figure 1}

In addition, for many students in the Northwest, misconceptions about the Latino population need to be brought to the forefront. The concept maps help draw on these stereotypes, but as many of my 
students have remarked, they feel that history and "facts" tell them the reality of other cultures' situations more than stereotypes. At this point, I move towards the history of rancheras (see Figure 2), including how this music was fundamental in transitioning the rural worker to the urban dwellings of the United States during the early to mid-twentieth century ${ }^{4}$, this music's relationship to the lower socio-economic class and fan-base, and Cesar Chávez's use of this music as a form of protest. ${ }^{5}$ This history reflects the idea that music can create change (something the students already understand), and learning this history and ideology leaves an appreciation of this music and gives memory to the histories (present and past) of migrant workers, farm workers, laborers, and their ancestors.

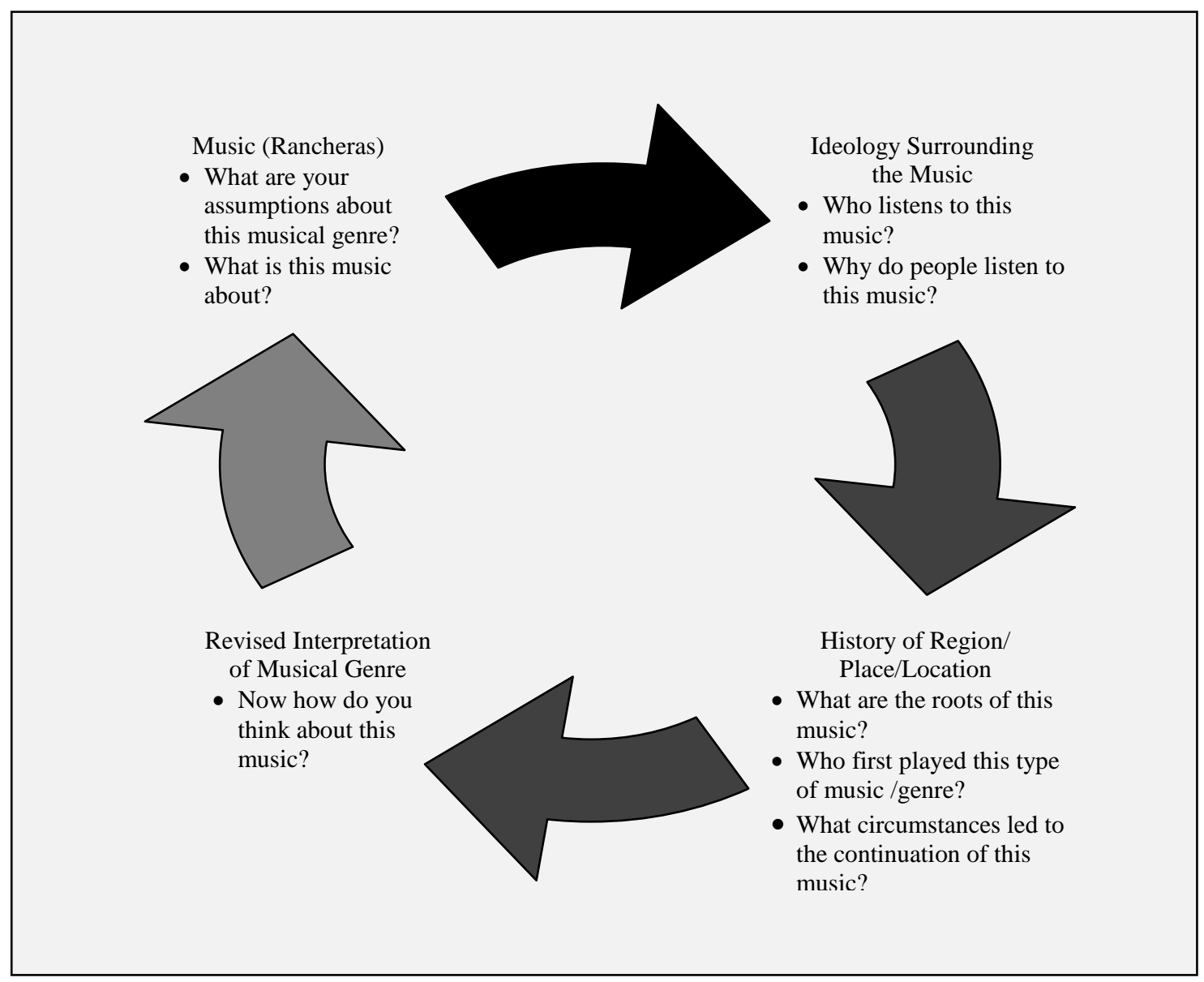

Figure 2

Through a historical reading of the song lyrics and the documentary, students are asked to focus on the connections between economics, nationalism, patriarchy, and race that are imbedded in this music. ${ }^{6}$ 
In fact, "intercultural conflict" is a term that is part of the discussions I incorporate into the class. Steven Loza's interpretation of Americo Paredes' theory recognizes "intercultural conflict" as that which remains alive in the consciousness of the Mexicano/Chicano and reminds them "of their ethnicity, traditions, and the political problems of their culture and community" (272). Thus, history and the ideology which has created it, is an important aspect of the reaction and response to the music that is created in Mexico, Latin America and the United States, especially along physical and socio-economic borderlands, and ranchera music is a part of this confrontation and cultural fusion, transnationally and individually. Thus, one of the culminating concept maps (see Figure 3) students complete after watching and discussing the documentary I discuss in the next section, is one where they focus on how the music is part of national and individual politics.

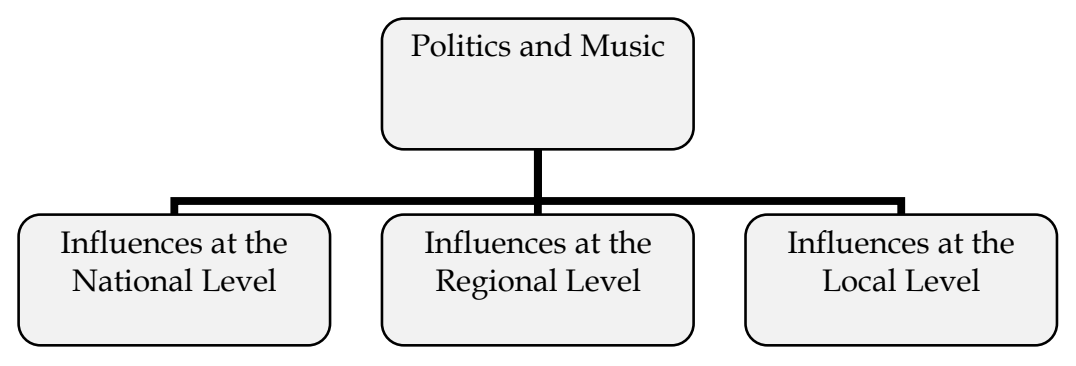

Figure 3

The Road to the Concept Maps: Music as a Visual Text - The Documentary

Valeria Sarmiento's 1982 documentary, Un Hombre, Cuando Es Hombre (A Man, When He Is A Man) examines the negative affects of ranchera music, asking the listener/viewer to understand the way the lyrics of these popular songs reflect the patriarchy and nationalism that affects Latina/os. This documentary carves out space for women's voices in interpreting rancheras. As a text worthy of rhetorical study in the classroom, this ethnographic-documentary investigates the language, the actual words and sentences that men and women use when describing their sexual conquests or their sexual lives and relationships and ties them to popular culture-namely music.

When bringing such a visual text into a classroom that questions prevailing racial, patriarchal and gender ideologies, we enter a room filled with students who may resist such questioning. Most of our 
students spend much of their day immersed in popular culture-most not in the form of literature or their parent's music for that matter. As educators, we come face to face with popular culture and the values that are set forth by the indoctrinators of our culture, and when we attempt to bring texts into the classroom that oftentimes contradict popular notions, we find resistance from the students. This documentary works well within the classroom walls as it begins with popular notions of gender, race, and class, and cleverly (and startlingly in many ways) moves away and towards a critical understanding of our comfort zones.

Un Hombre, Cuando Es Hombre is divided into four definable parts which students can break down rhetorically and easily. The first contains pastoral scenes that incorporate images of horses, animals, and dancers going through courtship rituals. The scenes are serenely quiet, allowing for the natural sounds to emerge. The second part contains interviews with boys and men discussing their courtship rituals such as kissing on the first date, putting hands on thighs, and having sex. As the men exude confidence in their storytelling, the language takes the tone of parody and the students, both male and female, do laugh at many of their tales. The men boast of their lovers, multiple wives, encounters with prostitutes, and compare themselves with studs because of the number of children they have produced. The laughter continues. As a storyteller herself, Sarmiento allows herself to be vulnerable ${ }^{7}$ and allows the laughter to continue. For the first half of the documentary, she holds a temporary armistice in the community between men and women by exposing the way language constructs myths that oppress women's actions - such as la Malinche, la Virgin de Guadalupe, and La Llorona that represent the virgin/ whore dichotomy ${ }^{8}$. What she does not yet do until she hits the denouement of the documentary, is show the consequences of these modes of thinking by forcing the viewer to reflect on the language they were once laughing at during the earlier part of the documentary. This in itself is disconcerting as the viewer begins to understand that we are all part of a rhetorical situation - in this case gender construction. The interviews Sarmiento conducts results in statements such as, "Women are like bread- the(y) must be eaten hot...or you'll never get your teeth in them," which loudly calls for the need of a feminist interpretation. 
The consequences of the laughter coming from our classroom and the language being used begin to take shape in the third section of the documentary where she interviews the women in combination with the men. This is when language becomes crucial to the representation of women. As Sarmiento introduces these abusive relationships, she weaves in popular Mexican rancheras as a vehicle to speak for the men. This allows her to present a feminist interpretation of these songs, while giving these women a voice within this music. She takes this parody one step further as she forces the student as spectator to choose whether or not they will react against the subject of sexuality and patriarchy when she abruptly introduces physical violence. Sexuality becomes a curse for many of the women interviewed as their traditionally-defined relationships and sexuality lead to their death. The men, whose language mirrors the patriarchal discourse of the rancheras (which I will elaborate on later in this essay), kill their wives and/or lovers. This offers an opportunity to discuss the archetypal Mexican figure, La Malinche that implies that a woman's sexual destruction is "necessary" for an "imagined [patriarchal and traditional] community" (Anderson) to survive.

The "imagined community" that assumes all Latinos make up a strong nationalistic culture, represses the discourse that results in these women's deaths because they did not faithfully fulfill their duties as wives or lovers. As the student as spectator is introduced to the women interviewed, the students are asked to revisit the oppression and myths such as la Malinche and la Virgen de Guadalupe that are embedded in the lyrics of some rancheras. By using the lyrics of this music, Sarmiento spells out the complexity of the racism, classism and sexism that surrounds the couples in this film, and as myth and reality become more difficult to understand and categorize, she directs the viewer's/students' attention to the way ranchera music is connected to the male gaze, and how this tradition is invested in the dominant ideology of patriarchy. Love, honor, and obedience for women are often intertwined in the lyrics of many rancheras and Sarmiento reproduces these cultural manifestations in her documentary as the discourse these women must resist in order to survive.

The women married to these men are silent through most of the documentary. Sarmiento's documentary is important because it uncovers and demystifies the apathy hidden in these women's 
passivity and silence. An example of this: Three women whom are married to the same man wait for "their" husband to return from his other patriarchal duties and families. When he arrives, his dinner is ready and each is "willing" to have sex with him if asked. All three women are married to the same man, thus echoing each other's actions. None speak against the "arrangement" they have with him, but instead, see this as a normal way of life. Because this is not a situation that offers these women an opportunity to exist beyond the home, Sarmiento illustrates the methods used by these men who depend on the silence of women to betray other women.

Another example of this rhetoric of silence or in this case, conformity, comes from a woman discussing her brother's life. She explains, "He'd bring a woman home—-say they're getting married— Sometimes I'd be there, we knew it was a lie. We knew he was already married with kids. They're all like him, they'll do anything...to get what they want from a woman." Unfortunately, this example shows how a woman's silence manifests itself in some aspects of Latino culture. Fortunately, Sarmiento's documentary, and this genre in particular, gives women the space for their discourse. In this case, it grants this woman the ability to voice her concerns about her brother and other men like him to a much larger audience than just the director, Sarmiento. Ironically, after having children of her own and becoming a single mother, she cannot find a voice within her new family. She is unable to change her brother's actions, and allows his actions to be mirrored by her own husband. But what this documentary is able to accomplish, is to sanction a place, or a zone for women to speak and be heard-even if their actions signify a much stronger patriarchy at work.

As the documentary moves along, Sarmiento takes the opportunity to illustrate how the lyrics found in ranchera music (a male discourse-reality) is distorted since women are not historically part of this utterance. The documentary (as well as the lyrics of traditional rancheras) illustrates that the female gaze is threatening for the male discourse/gaze. In order to maintain control of their honor and of their gaze, the men in the documentary find a solution through the death of a woman's discourse, and in the case of the men Sarmiento interviewed, the actual death of the women. 
Sarmiento makes this violent shift in her documentary, suturing the student as spectator from the men's lives that were becoming commonplace and humorous. Through the confessions these men give, the student understands that the men are listening to the music that upholds the macho image and the whore/virgin dichotomy, because even with their humble manners, the men continue to blame the women for leaving them with little choice but to punish them as is heard in the words of one of the men: "I always begged her not to treat me so. I couldn't keep her like a queen, but...on my mechanic's wages, I did my best for her," and she "made me feel: This woman hates me...but I'll make her love me." Sarmiento's use of lyrics from popular ranchera songs as her sub-text, clearly illustrates the connection between the music and the thoughts and actions of these men. Lyrics taken from the documentary's subtitles illustrate the popular song, "El Rey," which clearly echo the husband's discourse:

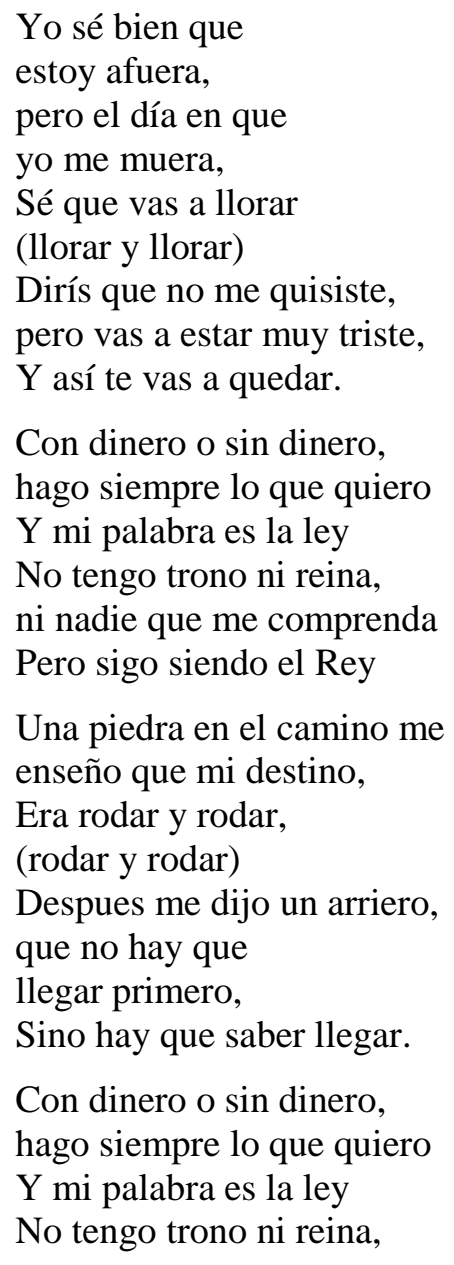

ni nadie que me comprenda Pero sigo siendo el Rey

\section{English translation}

I know very well that

I'm on the outside

but, on the day

that I die

I know you're going to cry

(cry and cry and cry and cry)

You'll say you didn't love me

but you're going to be very sad

and that's how you're going to stay

With money or without it I always do what I want and my word is the law(!) I have no throne, nor queen, nor anyone who understands me but I continue to be the King!

A stone in the road showed me that my destiny was to roll and roll (roll and roll and roll and roll) Later, a mule skinner told me that you don't have to be the first to arrive but only to know how to arrive. 
With money or without it

I always do what I want
I have no throne, nor queen, nor anyone who understands me but I continue to be the King! and my word is the law(!)

By using the lyrics of this "traditional" song, Sarmiento plays with a patriarchal and nationalistic pathos.

And whether the students understand the Spanish being spoken, or are working through the act of translation on the bottom of the screen, the sub-titles provide a new experience for the student as spectator, where the words become hauntingly familiar and reiterate the sexual comments and innuendos made previously in the documentary by the boys and the men. Sarmiento cleverly inserts these songs into the film, and the men's mimicking of these song lyrics becomes obvious.

In the end, the two men who were imprisoned for killing their wives for having affairs or not fulfilling their domestic duties, illustrate that the macho image and the myth of the virgin/whore dichotomy is believed in and exercised by many individuals through various artistic forms. Thus, the choices women have, whether economic, political or individual are not as easily accessible to these women. Simply stated, they can access them through marriage. Spectators in the United States whose ideology states individualism are left wondering who has taken away these women's independence. The musicians mentioned cannot be solely blamed for their retelling of virgin/whore myth. Educators can take this opportunity to look at the record companies, the lyricists, the merchandise companies, and the culture that buys and listens to this music, including American country music, rock, rap, or any genre of music that positions women in oppressed roles.

Similar to Latin American music, "most examinations of rap music and Hip-Hop culture critique rap as a masculine discursive space and seldom look at Black women's experiences within this space. With the exception of critiques of misogyny and sexism in rap music and Hip-Hop culture, how rap music and Hip-Hop culture influence Black womanhood goes unexplored” (Pough 83). Educators can begin to look toward critiques of women in popular Latin American music through critics such as Frances R. Aparicio and Cándida Jáquez (Musical Migrations), or Hip-Hop culture and rap music through critics such as Gwendolyn Pough, bell hooks, and Tricia Rose, because as Pough has stated in Check It While I Wreck It: Black Womanhood, Hip-Hop Culture, and the Public Sphere, scholars need "to take on the task 
of writing women into the history of Hip-Hop and validating the creative contributions of women to the field" (83). Thus, students can take this exercise (concept maps) and then in a written analysis requiring research they can re-interpret the use of music scores in their favorite films or video games, paying attention to women artists, and gender and economic roles. The language that surrounds the virgin/whore dichotomy and female archetypes is strong, therefore Ranchera music or music in general provides an energetic forum where educators can question the reality that is being presented and ask for a revised reality that celebrates and maintains women's agency. The women in Sarmiento's documentary provide a model where the lack of female language has dangerous consequences. Sarmiento insists that the male language restricts a woman's will (and perhaps the man's will) and parodies the language that makes violence on women acceptable. Therefore, the rhetoric of violence and oppression found in this music can lead students to a rereading of the wor(l)d.

\section{Essentialize the Music, Essentialize the Self}

In examining ranchera's kaleidoscopic nature, Homi Bhabha's words acted as a catalyst for my analysis of this music and its uses in the classroom. In Gary A. Olson and Lynn Worsham's interview with Bhabha, "Staging the Politics of Difference," he articulates, "literacy is absolutely crucial for a kind of ability to be responsible to yourself, to make your own reading to yourself, to make your own reading within a situation of political and cultural choice[....]Literacy is very important for the representation of 'self,' by which I don't mean individuals, just self-representation within a democratic foundation” (29). In representing the self, music is and has been a common thread between generations. For many generations, parents find it useful to compare Lady Gaga and Britney Spears to Madonna and Madonna to Marilyn Monroe, situating their teenager and memories of their own adolescence as rebelling against what's "normal." This essay pushes forward the idea that the self can negotiate identity by choosing which texts can and will be a part of their lives and how the self will then interact with or interpret those texts that are outside of that canon. Thus, when a student comes face to face with a text they may not fully understand, it has to become a matter of personalizing the historical and historicizing the personal in order to move 
through that textual moment. In stating this, I move the idea forward that students must negotiate conflicting rhetorics that arise from socio-cultural systems in order to come to an understanding of a text that is unfamiliar to them.

And even though rancheras are usually not the dominant genre playing on the radio or television at most universities, rancheras are heard in the margins of most of our students' lives. Those margins are in/visible to many depending on who is and how one is listening and which rhetorics are privileged in the area. This advances a hybrid rhetoric which illustrates multi-literacy, and in this case specifically, rancheras are a hybrid-rhetoric because of the German and Polish influences found in the music, but also because of the strategies the listeners of this music must perform in order to push for this music's continuation. This music actively pushes listeners to think from a South-North paradigm because of its socio-location.

Along similar lines, especially in reference to texts, Emma Perez, discusses how many Chicana texts are always situated outside of the margins. In The Decolonial Imaginary, she places Chicana counter-discourses outside or working against U.S. rhetoric: "My contention is that Chicana history has been a conscious effort to retool, to shift meanings and read against the grain, to negotiate Eurocentricity whether within European historical models or within the paradigms of United States historiography” (xvii). This leads to an examination of how specific Latino/a literacies are formed in the classroom and which rhetoric is privileged. Using rancheras in the classroom provides an opportunity to locate a Latina/o text (music or film) within Perez's historical models, while asking students to provide information about their linguistic and rhetorical choices in the classroom. By placing this music within the European model and the classroom, it forces students to revision this music as part of "American" culture, as part of the history of this country, and as a political and historical text which is constantly rewritten by the forces of South American, Central American, Caribbean, Mexican, and United States cultures. As stated earlier, it is important to ask students what their preconceived ideas are about this type of music, which can be done using concept maps which redirect thought to a South/North paradigm. Oftentimes, this music falls directly into the stereotypical box that has been prepared for them by mainstream media, with images 
being served to them; including but not limited to men with beer bottles in their hands and scantily-clad women around them, or as the ideal Spring break destination where they serve $\$ 1.00$ well drinks, etcetera. But when this music is compared to the country music of the United States that is more familiar ("there's a tear in my beer" genre), the discussion changes. It is a matter of personalizing the historical, but what we must not lose sight of is historicizing the personal and making a student's education transnationalwith a critical examination of borders (personal, political, gendered, sexual, and economic).

In conclusion, I return to Guerra's transcultural repositioning and Kells and Balester's myth of la frontera as ways to engage students to analyze their relationship to a social text-music. Within this discussion, I also return to my own experiences with ranchera music and the fact that I resisted my parents' music for so long, first because of the nationalism it implied, and then later because of the antifeminism it inherently carried. In using rancheras in the classroom, my goal is to locate how often students (sub)consciously make choices to essentialize their own identity in an attempt to negotiate through a privileged rhetoric and work within a European historical and linguistic model—especially in the music that we listen to as children and teenagers. In other words, do students choose the music they listen to consciously? Thus I use Shor's definition of Freire's term, critical subjectivity as that which "connects student experience to reflective habits of mind and to projects for change" (viii). As this essay illustrates, a transnational Latina/o discourse must be a part of this conversation as educators and students continue to negotiate conflicting cultural rhetorics in the classroom.

\section{End Notes}

${ }^{1}$ This music or rancheras is known as a "particular type of rural-based canción that became popular during the early twentieth century. The content of these songs spoke about male notions of honor, love, and life in a rural environment, usually the rancho" (San Miguel 11). 
This is an author-produced, peer-reviewed version of this article. The final, definitive version of this document can be found online at Feminist Teacher, published by University of Illinois Press. Copyright restrictions may apply.

${ }^{2}$ José Angel Gutiérrez (2003) discusses border radio, AM/FM transmission, and rules and regulations set by the Federal Communications Commission (FCC) about Mexico and U.S. radio relations in "Chicano Music: Evolution and Politics to 1950" (146-174).

3 This idea is best exemplifies in Pat Mora's Nepantla (1993) when she feels the liberation of blaring ranchera music from her radio while driving down an Ohio road with the windows open (12).

${ }^{4}$ Yolanda Broyles-González describes this transition as: "the canción ranchera is a part of the contested space between the two overlapping cultural geographies of a migratory people with long roots. Seen historically, the emergence and mass popularization of the canción ranchera is inversely related to raza's presence on the landbase. In the 1930s most raza still lived and worked in rural environs; today over 90 percent live in urban centers" (189).

${ }^{5}$ This music, along with corridos (both which reach a large underserved population) captures the economic situation of its listeners. Because of this, the music fan base remains steady, especially in the United States. María Herrera-Sobek describes Cesar Chávez's use of music as a form of protest in Northward Bound: The Mexican Immigrant Experience in Ballad and Song:

One instrument Chávez used for his membership drives was singing. He learned this technique through his association with a Protestant minister when he was invited to participate in a humble Protestant service. He noticed that there was a considerable amount of singing and clapping of hands. Furthermore, the people looked very happy in spite of their meager circumstances. Chávez deduced correctly that the singing and music would enhance his union meetings and inspire the people. (179)

${ }^{6}$ Critics, such as Américo Paredes and Anzaldúa have done much to reformulate the stereotypical images this music has created, in order to understand that these songs are part of the "borderland" existence. In the foreword to Américo Paredes' A Texas-Mexican Cancionero, Manuel Peña understands Paredes's text as showcasing how music (in this case, Texas-Mexican conjunto) "represents a response to intercultural conflict, although it is a product of class dynamics as well. Deeply rooted in a working-class, norteño culture, the conjunto projects a strong ideology that is in substantial opposition not only to a 
hostile Anglo culture but to that of an increasingly assimilationist Mexican American middle class" (xxvxxvi). Musically, there are clear differences between the conjunto and the ranchera, but what I wish to extrapolate from this is the idea that the listener makes meaning from music according to their social context and as a response to "intercultural conflict."

${ }^{7}$ I use the term "vulnerable" to indicate that many of the comments producing laughter are made by men about women on a daily basis. She remains vulnerable as the producer of this text, understanding that these comments are offensive to many (and I include students in the classroom). I also use this term to illustrate Ruth Behar's (1996) understanding of “the vulnerable observer.” In The Vulnerable Observer, she writes,

Vulnerability does not mean that anything personal goes. The exposure of the self who is also spectator has to take us somewhere we couldn't otherwise get to. It has to be essential to the argument, not a decorative flourish, not exposure for its own sake. It has to move us beyond that eclipse into inertia, exemplified by Rolf Carlè, in which we find ourselves identifying so intensely with those whom we are observing that all possibility of reporting is arrested, made inconceivable. (14)

${ }^{8}$ Mexico had already seen the colonization of its religion when the Spanish conquered the Indian population in the $16^{\text {th }}$ century. The story of La Malinche came to fruition, thus creating the first mestizo/a (Mexican). Because of this “mestizaje,” Doña Marina/ Malinche/ Malintzin were considered to be the traitor of her race - the representative "whore" of the virgin/whore dichotomy. Alongside this event, when Juan Diego saw the la Virgen de Guadalupe on December 9, 1531, her appearance was atop Tepeyac, "the place where Tonantsi had been worshiped by the Nahuas and where a temple to her had stood" (Anzaldúa 28). In many ways the Spaniards used her to replace the goddess Tonantzìn with a more malleable figure. In the year 2002, Pope John Paul II indoctrinated La Virgen de Guadalupe as a saint of the Catholic Church, making her legitimate to the Catholic Church in Spain even though she has always been a legitimate saint in the eyes of the Mexican population. And finally, La Llorona represents the 
fallen woman who either kills her children (sometimes her husband is said to have murdered the children) or husband, falls into the category of a "bad mother/woman," and is therefore placed in a category that is not submissive and humble.

\section{Works Cited}

Anderson, Benedict. Imagined Communities. London: Verso, 1983.

Anzaldúa, Gloria. Borderlands/La Frontera: The New Mestiza. San Francisco: Aunt Lute Books, 1987.

Behar, Ruth. The Vulnerable Observer: Anthropology that Breaks Your Heart. Boston: Beacon P, 1996.

Broyles-González, Yolanda. 1994. "Ranchera Music(s) and the Legendary Lydia Mendoza: Performing Social Location and Relations.” In Chicana Traditions: Continuity and Change, ed. Norma E. Cantú and Olga Nájera-Ramírez, 183-206. Urbana: U of Illinois P.

Dunbar-Odom, Donna. 1999. "Speaking Back with Authority: Students as Ethnographers in the Research Writing Class." In Attending to the Margins: Writing, Researching, and Teaching on the Front Lines, ed. Michelle Hall Kells and Valeria Balester, 7-22. Portsmouth, NH: Boynton/Cook Publishers.

Guerra, Juan C.. 2004. "Emerging Representations: Situated Literacies, and the Practice of Transcultural Repositioning.” In Latino/a Discourses: On Language, Identity \& Literacy Education, ed. Michelle Hall Kells, Valeria Balester, and Victor Villanueva, 7-23. Portsmouth, NH: Boynton/Cook Publishing.

Gutiérrez, José Angel. 2003. "Chicano Music: Evolution and Politics to 1950.” In The Roots of Texas Music, ed. Lawrence Clayton and Joe W. Specht, 146-174. College Station: Texas A\&M U P. 
Herrera-Sobek, María. 1998. "The Corrido as Hypertext: Undocumented Mexican Immigrant Films and the Mexican/Chicano Ballad." In Culture Across Borders: Mexican Immigration \& Popular Culture, ed. David R. Maciel and María Herrera-Sobek, 227-258. Tucson: U of Arizona P.

---. Northward Bound: The Mexican Immigrant Experience in Ballad and Song. Bloomington: Indiana U $\mathrm{P}, 1993$.

Jáquez, Cándida F.. 2002. “Meeting La Cantante Through Verse, Song, and Performance.” In Chicana Traditions: Continuity and Change, ed. Norma E. Cantú and Olga Nájera-Ramírez, 167-182. Urbana: U of Illinois P.

Kells, Michelle Hall and Valeria Balester. 1999. "Introduction: Voices From the Wild Horse.” In Attending to the Margins: Writing, Researching, and Teaching on the Front Lines, ed. Michelle Hall Kells and Valeria Balester, xiii-xxiii. Portsmouth, NH: Boynton/Cook Publishers.

Loza, Steven. Barrio Rhythm: Mexican American Music in Los Angeles. Urbana: U of Illinois P, 1993. Mora, Pat. Nepantla: Essays from the Land in the Middle. Albuquerque: U of New Mexico P, 1993. Negrete, Jorge."'Mexico Lindo y Querido." Leyendes del Cine Mexicano: Pedro Infante y Jorge Negrete, Vol. I. Orfeon Videovox, S.A., 1997.

Nilson, Linda B. Teaching at Its Best: A Research-Based Resource for College Instructors, $2^{\text {nd }}$ Edition. San Francisco, CA: Anker Publishing, 2003.

Olson, Gary A. and Lynn Worsham. 1999. “Staging the Politics of Difference: Homi Bhabha’s Critical Literacy." In Race, Rhetoric, and the Postcolonial, ed. Gary A. Olson and Lynn Worsham, 3-42. Albany: State U of New York P.

Paredes, Américo. A Texas-Mexican Cancionero: Folksongs of the Lower Border. Austin: U of Texas P, 1976.

Peña, Manuel. 1976. "Foreword.” In A Texas-Mexican Cancionero: Folksongs of the Lower Border, xxvxxxi. Austin: U of Texas P. 
---. 2001. "From Ranchero to Jaitón: Ethnicity and Class in Texas-Mexican Music (Two Styles in the Form of a Pair)." In Puro Conjunto: An Album in Words and Pictures: Writings, Posters, and Photographs from the Tejano Conjunto Festival en San Antonio, 1982-1998, ed. Juan Tejeda and Avelardo Valdez, 31-69. Austin: Center for Mexican American Studies, The University of Texas at Austin.

Pérez, Emma. The Decolonial Imaginary: Writing Chicanas Into History. Bloomington: Indiana U P, 1999.

Pough, Gwendolyn D.. Check It While I Wreck It: Black Womanhood, Hip-Hop Culture, and the Public Sphere. Boston: Northeaster UP, 2004.

San Miguel, Jr., Guadalupe. Tejano Proud: Tex-Mex Music in the Twentieth Century. College Station, TX: Texas A\&M U P, 2002.

Sarmiento, Valeria, dir. 1982. Un Hombre Cuando Es Hombre/ A Man When He's a Man. NY: Women Make Movies, Inc..

Shor, Ira. 1999. "Preface: Freire's Critical Subjectivity: Questioning Self in Society." In Attending to the Margins: Writing, Researching, and Teaching on the Front Lines, ed. Michelle Hall Kells and Valeria Balester, vii-x. Portsmouth, NH: Boynton/Cook Publishers.

Soong, Roland. “Regional Music of Mexico.” Zona Latina. November 22, 2001. http://www.zonalatina.com/Zldata206.htm. (15 June 2010). 